\title{
FAKTOR-FAKTOR YANG MEMPENGARUHI KEPATUHAN APARATUR PEMERINTAH ATAS PROSEDUR PENGADAAN BARANG/JASA
} (Studi Kasus Pada Aparatur Pemerintah Kabupaten Kediri)

\author{
NENNY DWI AGUSTINA \\ Universitas Brawijaya
}

\begin{abstract}
Abstrak
Penelitian ini bertujuan untuk mengetahui faktor-faktor apa sajakah yang mempengaruhi kepatuhan aparatur pemerintah atas peraturan pengadaan barang/jasa. Penelitian ini merupakan confirmatory research yang dilaksanakan di instansi pemerintah yang berada di bawah naungan Pemerintah Kabupaten Kediri dengan desain penelitian survey dan kuesioner sebagai instrumen penelitian. Terdapat 116 responden dari 8 instansi pemerintah di kabupaten Kediri yang ikut berpartisipasi dalam pengumpulan data yang kemudian dianalisis dengan alat uji regresi dengan bantuan program SPSS versi 20. Hasil studi menunjukkan bahwa : (1) SPI berpengaruh positif dan signifikan terhadap kepatuhan aparatur pemerintah, (2) sistem kompensasi tidak berpengaruh terhadap kepatuhan aparatur pemerintah, (3) kecerdasan emosi berpengaruh positif dan signifikan terhadap kepatuhan aparatur pemeriintah, (4) pengamalan nilai-nilai spiritual terhadap kepatuhan aparatur pemerintah dan (5) SPI, sistem kompensasi, kecerdasan emosi, dan pegamalan nilai-nilai spiritual secara simulatan berpengaruh terhadap kepatuhan aparatur pemerintah. Artinya bahwa peran SPI dan kecerdasan emosi dapat terbukti efektif meningkatkan kepatuhan aparatur pemerintah.
\end{abstract}

Kata kunci : Kepatuhan, SPI, Sistem Kompensasi, Kecerdasan Emosi, Pengamalan NilaiNilai Spiritual.

\section{PENDAHULUAN}

Melalui pengadaan barang/jasa yang baik, maka pemerintah dapat menciptakan sarana prasarana penunjang yang baik pula dan diharapkan public goods yang tercipta dapat diterima masyarakat dengan maksimal. Pemerintah mengharapkan melalui public goods yang baik maka rakyat dapat melakukan berbagai kegiatan ekonomi dengan aman dan nyaman sehingga perekonomian negara dapat berkembang. Sebaliknya, apabila pengadaan barang/jasa dilakukan dengan tidak maksimal maka akan dihasilkan pelayanan pada publik yang tidak maksimal pula. Padahal, inti dari tugas suatu pemerintahan adalah melakukan pelayanan terhadap publik, jika pelayanan itu dicederai, maka yang merasakan kerugian adalah rakyat. Dalam upaya menjaga proses pengadaan barang/jasa terbebas dari penyalahgunaan pihak-pihak berkepentingan yang dapat merugikan pemerintah dan rakyat maka pemerintah mengeluarkan paket peraturan dan perundang-undangan perihal proses 
pengadaan barang/jasa. Prosedur pengadaan barang/jasa dibuat berlapis dan dengan banyak persyaratan untuk mendorong kehati-hatian aparatur pemerintah dalam melakukan pengadaan, pengadaan harus dilakukan sesuai dengan tujuan dan fungsinya demi pelayanan terhadap rakyat.

Potret pengadaan barang dan jasa pemerintah yang sempat diketahui melalui sejumlah studi yang dilakukan oleh berbagai pihak memperlihatkan kerentanan sistem yang digunakan terhadap terjadinya tindak pidana korupsi. United Nations Development Programme (UNDP) memperkirakan korupsi yang terjadi secara sistimatik dalam pengadaan barang dan jasa pemerintah ini diperkirakan sebesar 20$25 \%$ dari total belanja pemerintah atau kurang lebih senilai 200 triliyun dollar per tahun. Sejumlah fakta di atas setidaknya memperlihatkan bahwa terjadi ketidakefektifan dalam sistem pengadaan barang dan jasa pemerintah. Ketidakefektifan sistem serta realitas terjadinya pelanggaran atas prosedur pengelolaan keuangan negara seperti yang diungkap sebelumnya juga tampak terjadi dalam konteks Indonesia. Permasalahan yang terjadi seputar kepatuhan seseorang terhadap kepatuhan hukum sebenarnya banyak diteliti di dalam kajian ilmu psikologi maupun sosial. Menurut Tyler (Saleh, 2004) terdapat dua perspektif dalam literatur sosiologi mengenai kepatuhan kepada hukum, yang disebut instrumental dan normatif. Perspektif instrumental mengasumsikan individu secara utuh didorong oleh kepentingan pribadi dan tanggapan terhadap perubahanperubahan yang berhubungan dengan perilaku. Perspektif normatif berhubungan dengan apa yang orang anggap sebagai moral dan berlawanan dengan kepentingan pribadi.

Faktor kepatuhan pelaku terhadap peraturan juga dilteliti oleh Baiman (1990) yang menjelaskan bahwa ketika terjadi konflik antara pengelola dan prinsipal sehingga perilaku pengelola menjauh dari kontrak yang disepakati, kontrak bisa diperbaiki melalui revisi sistem kompensasi dan meningkatkan biaya untuk perbaikan sistem pengawasan melalui desain Sistem Pengendalian Internal (SPI).

Selain faktor kompensasi dan pengendalian internal organisasi, keterlibatan faktor moral berperan penting terhadap bagaimana seseorang menjadi puas terhadap tingkat kompensasi yang diterima dan memiliki manfaat untuk ikut mengendalikan perilaku seseorang. Moral tersusun dari berbagai nilai yang didapat seorang individu melalui interaksinya dengan Sang Pencipta dan individu lainnya. Interaksi dengan Sang Pencipta dilihat melalui pengamalan nilai-nilai spiritual sedangkan interaksi dengan individu lainnya tercermin sebagai kecerdasan emosi (Thoyibatun, 2009). Oleh karena itu, dalam penelitian ini dipilih kecerdasan emosi dan pengamalan nilai-nilai spiritual sebagai upaya mengadakan studi yang utuh tentang faktor-faktor yang mempengaruhi kepatuhan aparatur pemerintah terhadap prosedur dalam prosedur pengadaan barang dan jasa. Sebab, dengan kecerdasan emosi dan pengamalan nilai-nilai spiritual dapat diperoleh kontrol kebenaran yang lebih kuat. 
Berdasarkan penelitian yang telah diuraikan sebelumnya diperoleh informasi yang bervariasi tentang faktor-faktor yang menyebabkan kepatuhan terhadap peraturan pengadaan barang dan jasa. Hasil penelitian tertentu menegaskan bahwa faktor tersebut adalah faktor SPI, sistem kompensasi dan asimetri informasi. Penelitian yang lain mengatakan karena faktor perilaku tidak etis. Oleh karena itu, perlu dibuktikan kembali akan anggapan pengaruh kecerdasan emosi dan pengamalan nilai-nilai spiritual terhadap tingkat kepatuhan terhadap peraturan perlu dikaji lebih lanjut.

\section{KAJIAN LITERATUR}

\section{Teori Kepatuhan}

Teori kepatuhan dalam literatur ilmu psikologi, dan sosiologi menekankan pada pendorong internal perilaku manusia dan faktor-faktor penentu secara sosial dalam suatu analisis normatif perilaku patuh (Chen, 2005; Chen dkk, 2006). Terdapat beberapa teori yang menjelaskan kepatuhan, di antaranya adalah teori compliance dan teori obedience. Kerumitan terjadi karena pada umumnya dua istilah di atas sama-sama diterjemahkan ke dalam bahasa Indonesia sebagai kepatuhan. Dua teori ini akan dielaborasikan untuk menjelaskan fenomena perilaku tertentu, yang dalam hal ini adalah perilaku tidak patuh. Menurut Green dan Kreuter (2005) perilaku kepatuhan dapat berupa perilaku patuh (compliance) dan perilaku tidak patuh (non compliance). Sehingga dalam penelitian ini, kepatuhan aparatur negara adalah segala tindakan aparatur negara dalam pelaksanaan prosedur pengadaan barang/jasa.

\section{Prosedur Pengadaan Barang/Jasa Pemerintah}

Schiavo-Campo dan Sundaram (2000) dalam Sartono (2006) mendefinisikan pengadaan barang/jasa pemerintah (government procurement) sebagai perolehan barang, jasa dan prasarana umum dalam waktu tertentu yang menghasilkan nilai terbaik bagi pemerintah maupun bagi masyarakat). Lebih jauh Schiavo-Campo dan Sundaram (2000) dalam Sartono (2006) mengungkapkan adanya karakteristik pengadaan barang / jasa di sektor privat (swasta) yang tidak ada pada pengadaan di sektor pemerintah. Beberapa karakteristik pengadaan barang/jasa disektor swasta yang tidak ada pada pengadaan barang/jasa di sektor pemerintahan antara lain :

1. Tidak terlalu menekankan proses tender kompetitif secara formal, Dokumentasi prosedur pengadaan dan konflik kepentingan yang mungkin terjadi. 
2. Lebih menekankan untuk membeli barang yang memberikan high value sepadan dengan harganya, dan menunjuk kontraktor yang akan mampu memberikan kualitas jasa yang tinggi dengan harga yang kompetitif.

3. Dimensi akuntabilitas yang dituntut lebih ditekankan pada hasil (result) dan bukan pada proses pengadaan itu sendiri.

Dalam pengadaan barang/jasa di sektor pemerintah justru berlaku hal yang berbeda, dimana proses dan dokumentasi atas kegiatan menjadi hal yang diperhatikan dan diatur, demikian pula dengan adanya konflik kepentingan (sesuai dengan Teori Agensi) yang mungkin terjadi. Dalam hal pekerjaan/barang yang diadakan, biasanya lebih menekankan pada harga terendah (lowest cost) dengan tetap memenuhi kualitas dan spesifikasi yang ditetapkan.

\section{Sistem Pengendalian Intern (SPI)}

Pengendalian intern didefinisikan sebagai rencana, organisasi dan metode bisnis yang dipergunakan untuk menjaga asset, memberikan informasi yang akurat dan handal, mendorong dan memperbaiki efisiensi jalannya organisasi, serta mendorong kesesuaian dengan kebijakan yang telah ditetapkan (Romney dan Steinbart, 2004; Bodnar dan Hopwood, 2004). Wilopo (2006) mengukur efektivitas SPI berdasarkan 5 indikator, yaitu (1) penerapan wewenang dan tanggung jawab, (2) pencatatan transaksi, (3) pengendalian fisik, (4) sistem akuntansi, (5) pemantauan dan evaluasi. Kelima indikator tersebut merupakan hasil eksplorasi dari SPAP seksi 319 tentang pertimbangan atas Pengendalian Intern dalam Audit Laporan keuangan (IAI, 2001).

Telaah terhadap ketentuan SPAP (IAI, 2001) dan pendapat COSO (1998) pada penelitian ini diikuti pendapat bahwa SPI tercapai jika bentuk SPI yang dikembangkan dan usaha orang-orang yang terlibat selaras dengan maksud memberi jaminan yang memadai bahwa tujuan organisasi akan terealisasi. Oleh karena itu, SPI akan diukur dengan indikator yang berkenaan dengan bentuk fisik SPI dan kapasistas pelaksanaan para pelaku dalam mendukung tercapainya tujuan SPI.

\section{Sistem Kompensasi}

Kompensasi merupakan komponen biaya yang dibayarkan oleh organisasi pada karyawan, baik yang menduduki jabatan sebagai pengelola, pejabat tertentu, ataupun sebagai karyawan biasa. Bagi karyawan kompensasi merupakan faktor yang menentukan tingkat kesejahteraan mereka, sedangkan organisasi menganggap kompensasi sebagai komponen biaya yang akan mempengaruhi efisiensi dan profitabilitas. Oleh karena itu, organisasi perlu hati-hati dalam mengontrol dan mendesain kompensasi supaya dua kepentingan tersebut dapat diakomodasi. Hal tersebut merupakan tantangan bagi organisasi untuk membuat sistem kompensasi 
yang tepat agar mampu mendorong karyawan berprestasi secara optimal (Leopold, 2002).

Sistem kompensasi adalah desain atau standar yang menjadi pertimbangan dalam menentukan jumlah kompensasi yang dibayarkan pada pengelola, pejabat atau karyawan yang tercakup dalam struktur kompensasi. Hal penting sehubungan dengan sistem kompensasi adalah persepsi orang yang menerima kompensasi terhadap sistem kompensasi yang berlaku pada dirinya. Persepsi berarti sebagai proses yang ditempuh individu untuk mengorganisasi dan menafsirkan kesan indra agar bermakna bagi lingkungan dan dirinya. Robbins (2001) menyebutkan bahwa perilaku orang di dalam organisasi lebih banyak didasarkan atas persepsinya mengenai realitas bukan berdasar realitas itu sendiri. Oleh karena itu, sistem kompensasi dalam penelitian ini dimaksudkan sebagai persepsi penerima kompensasi terhadap standar yang digunakan sebagai dasar dalam menghitung kompensasi yang menjadi haknya.

\section{Kecerdasan Emosi}

Oxford Englis Dictionary mendefinisikan emosi sebagai campuran kegiatan pikiran, perasaan, nafsu dan pikiran. Emosi sulit digambarkan secara tepat dan sebagai gambaran kasar dapat dikatkan bahwa emosi merujuk pada keadaan pikiran dan perasaan, biologis dan psikologis yang bercampur dan terwujud sebagai serangkaian kecenderungan untuk bertindak. Konsep kecerdasan emosi pertama kali digagas oleh Salovey dan Mayer tahun 1990 dimana mereka mendefinisikan kecerdasan emosi sebagai kemampuan merasakan, memahami, menerapkan secara efektif daya dan kepekaan emosi sebagai sumber energi, informasi, koneksi, dan pengaruh yang manusiawi (Cooper dan Sawaf, 1998). Lebih jauh dikemukakan oleh Goleman (2003) bahwa kecerdasan Intelektual menyumbangkan kira-kira $20 \%$ bagi faktorfaktor yang menentukan sukses dalam hidup, sedangkan yang $80 \%$ diisi oleh kekuatan-kekuatan lain. Kecerdasan emosi berhubungan dengan kesadaran diri yang memandu seseorang untuk mengakui dan menghargai perasaan diri sendiri dan orang lain yang terwujud dalam perilaku yang efektif. Agustian (2004) dan Goleman (2005) menunjukkan bahwa kecerdasan emosional dan hasil olahnya diwujudkan dalam berbagai kecakapan

Melengkapi peranan faktor kecerdasan emosional terhadap perilaku etis dan tidak etis manusia, lebih lanjut Agustian (2001) mengemukakan bahwa kecerdasan emosional mengakibatkan timbulnya kesulitan atau kepincangan jika dalam praktiknya dipisahkan dengan pengamalan nilai-nilai spiritual. Keduanya harus digabungkan dan dijalankan secara bersama-sama sehingga menjadi harmonis antar sesama manusia dan harmonis dengan Tuhannya (Triyuwono dan Roekhuddin, 2000; Ludigdo, 2005). 


\section{Pengamalan Nilai-Nilai Spiritual}

Spiritual berasal dari bahasa latin spiritus yang berarti prinsip yang memvitalisasi suatu organisme, atau spientia yang berarti kearifan. Pengamalan nilai-nilai spiritual diartikan sebagai menggunakan nilai sebagai dasar berperilaku dan mengarahkan pencapaian makna sebagai tujuan dalam berperilaku. Pengamalan nilai-nilai spiritual mencakup kecerdasan untuk menghadapi dan memecahkan persoalan makna dan nilai yang berkaitan dengan hal-hal transeden (Zohar dan marshall, 2002). Kecerdasan ini melampaui kekininan dan pengalaman manusia serta merupakan bagian terdalam serta terpenting dari manusia (Pasiak, 2002). Berdasar dimensi yang berbeda, spiritual tidak hanya diukur berdasarkan intensitas manusia tersebut melakukan ibadah, namun lebih kepada kemampuan untuk memberi makna ibadah terhadap setiap perilaku dan kegiatan, melalui langkah-langkah dan pemikiran yang bersifat fitrah, menuju manusia yang sesungguhnya (hanif), dan memiliki pola pemikiran tauhid (integralistik), serta berprinsip 'hanya karena Allah SWT' (Agustian, 2001).

\section{PENGEMBANGAN HIPOTESIS}

\section{Pengaruh SPI Terhadap Kepatuhan Prosedur Pengadaan Barang/Jasa}

SPI di pemerintahan daerah sebenarnya telah dikembangkan untuk memberikan jaminan bahwa aset organisasi telah dikelola sedemikian rupa sehingga dapat mendukung tercapainya tujuan organisasi. Namun, terdapat berbagai variasi tentang bagaimana SPI tersebut dilaksanakan. Sebuah penelitian menginformasikan bahwa bentuk SPI pada suatu organisasi tidak seberapa dipahami oleh anggota organisasi. Namun, anggota organisasi melaksanakan SPI dengan komitmen yang tinggi dan disertai akuntabilitas yang bertingkat-tingkat mulai dari kepada sesama manusia sampai kepada Tuhan, dan dalam bentuk kompleks yang meliputi aspek fisik, mental dan spiritual (Triyuwono dan Roekhuddin, 2000). Temuan penelitian tersebut memberikan makna bahwa praktik pengendalian internal yang kompleks dapat meningkatkan kualitas perilaku dan pertanggungjawaban pengelola. Tanggung jawab tersebut semakin baik ketika disertai kesadaran bahwa tanggung jawab tidak terbatas kepada pemilik organisasi, tetapi juga kepada Tuhan dan seluruh stakeholder yang tidak memiliki hubungan secara tidak langsung sekalipun. Berdasarkan dugaan ini hipotesis yang diajukan :

$\mathrm{H}_{1}$ : Sistem pengendalian intern berpengaruh terhadap kepatuhan prosedur pengadaan barang dan jasa aparatur pemerintah

\section{Pengaruh Sistem Kompensasi Terhadap Kepatuhan prosedur pengadaan Barang/Jasa}


Alternatif lain untuk mengatasi konflik dalam rangka mengendalikan perilaku pengelola agar memperhatikan kepentingan prinsipal adalah merevisi kontrak melalui koreksi terhadap sistem kompensasi pengelola (Jensen dan Meckling, 1976; Watt dan Zimmerman, 1986). Hal ini disebabkan karena ketika uang dijadikan sebagai bentuk penghargaan terhadap kinerja, banyak pekerja yang menyatakan ketidakpuasan terhadap uang tersebut, dan ini akan berpengaruh terhadap komitmen pekerja. Oleh karena itu, perbaikan sistem kompensasi diharapkan menjadi salah satu cara untuk memperbaiki perilaku dan kinerja yang diharapkan (Jensen dan Meckling, 2004; Watt dan Zimmerman, 1986).

Terdapat dua pendapat yang berhubungan dengan kompensasi dimana pendapat yang pertama mengatakan bahwa faktor uang atau desain kompensasi dapat digunakan untuk mempengaruhi munculnya perilaku yang diinginkan (Baiman, 1990; Banker, et al. 1998; Ribstein, 2002). Pendapat kedua mengatakan bahwa uang atau desain sistem kompensasi tidak selalu bisa digunakan untuk mempengaruhi munculnya perilaku yang tidak dinnginkan (Dallas, 2002; Pitchard, 1999).

Pendapat kedua terbukti dengan penemuan Wilopo (2006) pada BUMN dan Organisasi Publik di Indonesia menunjukkan bahwa perbaikan kompensasi melalui peningkatan gaji dan perbaikan promosi yang dipandang telah memadai ternyata tidak mampu menurunkan tindakan kecurangan keuangan. Hal tersebut di antaranya disebabkan adanya keinginan untuk memperoleh bonus atau jabatan yang lebih tinggi dan jumlah kompensasi yang diterima tidak sesuai dengan yang diinginkan dan hasil dari tindakan penyalahgunaan keuangan lebih besar dibandingkan kompensasi. Berdasarkan uraian di atas dapat disimpulkan bahwa sistem kompensasi yang diperbaiki diberi makna oleh pengelola secara berbeda dengan maksud yang dituju oleh pemberi amanah. Perilaku pengelola yang diinginkan muncul tetap dapat dibentuk dan diarahkan. Salah satu faktor yang bisa dimanfaatkan dalam hal ini adalah persepsi pengelola terhadap sistem kompensasi karena hal tersebut berperan sebagai motivasi bagi pengelola dalam berperilaku. Hipotesis yang diajukan berdasar dugaan tersebut :

$\mathrm{H}_{2} \quad$ : sistem kompensasi berpengaruh terhadap kepatuhan prosedur pengadaan barang/jasa

\section{Pengaruh Kecerdasan Emosi Terhadap Kepatuhan Prosedur Pengadaan Barang/Jasa}

Emosi memiliki peranan yang penting sebab dengan emosi yang sehat dan matang seseorang akan mampu memanfaatkan sebaik mungkin berapa pun tingkat pengetahuan yang dimiliki. Namun jika emosi bermasalah, seberapa besarnya tingkat intelektualitas yang dimiliki seseorang akan kesulitan untuk memanfaatkannya (Goleman, 2004). Oleh karena itu, emosi yang terkendali akan memberikan kontribusi yang signifikan bagi timbulnya sikap yang diharapkan dan 
keberhasilan pengelola bagi organisasi yang dikelolanya melalui berbagai cara (Vakola, et al. 2004; Mandell dan Pherwani, 2003). Kecerdasan emosional mengalami perkembangan dan pertumbuhan sehingga perlu dipelihara dan dikenali dengan lebih baik (Zohar dan Marshall, 2005). Melalui pendidikan dan pembelajaran kecerdasan emosional bisa ditingkatkan kapasitasnya dan bermanfaat sebagai kekuatan dalam memanfaatkan kemampuan yang lain.

Temuan Lam dan Kirby (2002) dan Bachri (2004) sependapat dengan pendapat di atas. Kedua peneliti tersebut membuktikan bahwa emosi berhubungan positif dengan kinerja kognitif seseorang. Bachri (2004) yang mengadakan studi terhadap karyawan STMT Trisakti Jakarta juga membuktikan bahwa emosi memiliki hubungan positif dengan perilaku kerja. Kecerdasan emosional membantu seseorang dalam memperbaiki hubungannya dengan sesama manusia, dengan kecerdasan emosional dan pengamalan nilai-nilai spiritual yang tertata seseorang dapat memanfaakan segala kemampuannya untuk berperilaku lebih baik, sebab dengan begitu mereka mengenal berbagai dimensi bentuk pertanggungjawaban (Triyuwono, 2000; Giacalone, 2003; Weaver dan Agle, 2002). Sehubungan dengan ini hipotesis yang diajukan :

$\mathrm{H}_{3}$ : Kecerdasan emosi berpengaruh terhadap kepatuhan prosedur pengadaan barang/jasa

\section{Pengaruh Pengamalan Nilai-Nilai Spiritual Terhadap Kepatuhan prosedur pengadaan Barang/Jasa}

Pemahaman seseorang terhadap ajaran keagamaan menumbuhkan sikap keagamaan seseorang dan selanjutnya akan mempengaruhi keputusan moral individu terhadap situasi yang bermuatan nilai-nilai etik (Clark dan Dawson, 1995). Keputusan tersebut digambarkan dalam berbagai dimensi yang bergerak sebagai garis kontinum, seperti antara benar dan tidak benar.

Pengamalan nilai-nilai spiritual membimbing hubungan seseorang dengan Tuhannya dan juga mendorong seseorang menjadi lebih baik hubungannya dengan sesama manusia. Pengamalan nilai-nilai spiritual yang dipahami secara utuh dan diinternalisasi dalam jiwa dan perilaku seseorang akan bepengaruh terhadap pertumbuhan emosinya. Dengan pengamalan nilai-nilai spiritual yang tertata seseorang dapat memanfaakan segala kemampuannya untuk berperilaku lebih baik, sebab dengan begitu mereka mengenal berbagai dimensi bentuk pertanggungjawaban (Triyuwono, 2000; Giacalone, 2003; Weaver dan Agle, 2002). Sehubungan dengan ini hipotesis yang diajukan :

$\mathrm{H}_{4}$ : Pengamalan nilai-nilai spiritual berpengaruh terhadap kepatuhan pengadaan barang/jasa 
Pengaruh sistem pengendalian internal, sistem kompensasi, kecerdasan emosi, dan pengamalan nilai-nilai spiritual terhadap kepatuhan prosedur pengadaan barang/jasa

Thoyibatun (2009) yang melakukan penelitian pada Perguruan Tinggi se-Jawa Timur menemukan adanya pengaruh antara sistem pengendalian internal, sistem kompensasi, kecerdasan emosi dan pengamalan nilai-nilai spiritual dengan ketidakpatuhan akuntansi. Thoyibatun (2009) menjelaskan bahwa kepatuhan datang dari luar diri dan dalam diri manusia. Faktor yang datang dari luar diri manusia merupakan faktor-faktor yang berasal dari lingkungan seperti adat, sistem pengendalian internal, sistem kompensasi, persepsi masyarakat dan lain sebagainya. Sedangkan faktor yang datang dari dalam diri manusia merupakan faktor-faktor yang merupakan pemahaman dan ketundukan sukarela manusia itu sendiri untuk patuh seperti kecerdasan emosi, pengamalan nilai-nilai spiritual dan sebagainya.

Untuk menjadikan seorang manusia menjadi benar-benar patuh terhadap suatu peraturan maka diperlukan suatu ketundukan yang sukarela dibandingkan dengan ketundukan yang berasal dari paksaan. Oleh karena itu, pengembangan faktor dari luar maupun dari dalam diri manusia itu sendiri harus dipupuk untuk menjadikan kepatuhan itu bersifat sukarela dan bertahan lama dalam diri seseorang. Thoyibatun (2009) melakukan uji simultan pada faktor sistem pengendalian iinternal, sistem kompensasi, kecerdasan emosi dan pengamalan nilai-nilai spiritual dan memperoleh hasil bahwa keempat faktor tersebut ternyata signifikan dengan kepatuhan seseorang terhadap peraturan. Sehubungan dengan hal ini hipotesis yang diajukan :

$\mathrm{H}_{5}$ : Sistem pengendalian internal, sistem kompensasi, kecerdasan emosi, pengamalan nilai-nilai spiritual berpengaruh terhadap kepatuhan prosedur pengadaan barang/jasa

\section{METODE PENELITIAN}

\section{Jenis Penelitian}

Jenis penelitian yang dilakukan adalah penelitian survey tipe confirmatory research (Newman, 1991), yaitu didasarkan pada pengambilan data melalui kuesioner untuk tujuan menguji kembali model yang ada dengan fakta empiris tentang hubungan kausal beberapa variabel. Penelitian ini lebih terfokus untuk mempelajari perilaku pengelola dan semua staf yang mendapat delegasi wewenang dan tugas untuk terlibat dalam Pengadaan Barang/Jasa. 


\section{Tempat Dan Waktu Penelitian}

Penelitian dilaksanakan di Pemerintahan Kabupaten Kediri. Pemerintah Kabupaten kediri dipilih untuk dipelajari karena kompleksnya kegiatan Pemerintah Kabupaten Kediri dalam hal pemberian pelayanan langsung kepada masyarakat, baik yang berupa barang maupun jasa. Apabila dalam proses pelayanan tersebut terjadi ketidakpatuhan terhadap peraturan pengelolaan keuangan di tingkat pemerintah kabupaten kediri maka imbasnya akan langsung dirasakan oleh masyarakat Kabupaten Kediri. Subjek ini menarik karena masih sedikitnya penelitian empiris yang dilakukan. Penelitian ini dilakukan selama sebulan, yaitu mulai 5 Desember 2013 hingga 20 Januari 2014.

\section{Sampling Penelitian}

Populasi dari penelitian ini adalah para Aparatur Sipil Negara (ASN) yang melakukan pengelolaan pada pengadaan barang/jasa di Kabupaten Kediri. Populasi tersebut kami berjumlah kurang lebih 432 orang dari 25 Satuan Kerja Perangkat Daerah (SKPD) di Kabupaten Kediri. Mengingat keterbatasan waktu dan tenaga maka penelitian ini tidak dapat melakukan pengambilan sampel penelitian secara menyeluruh di tiap-tiap SKPD. Peneliti melakukan pengambilan sampel penelitian pada 8 SKPD yang terdiri atas sekretariat daerah bagian pembangunan; Badan Perencanaan Pembangunan Daerah; Badan Pengelolaan Keuangan dan Aset Daerah; RSUD Kabupaten Kediri; Dinas Kependudukan dan Catatan Sipil; Dinas Kesehatan; Dinas Pekerjaan Umum; dan Dinas Pendidikan,Pemuda dan Olahraga. Jumlah kuesioner yang dibagikan oleh peneliti sebanyak 138 buah kuesioner, dari 138 buah kuesioner tersebut, kuesioner yang dikembalikan dan diisi dengan lengkap sebanyak 116 buah kuesioner. Untuk selanjutnya, 116 buah kuesioner inilah yang peneliti anggap sebagai sampel penelitian. Sampel yang telah didapatkan selama proses pengambilan data, peneliti anggap sesuai untuk memenuhi kebutuhan penelitian.

\section{Teknik Pengumpulan Data}

Prosedur pengumpulan data diperoleh dengan cara kuesioner yang bersifat tertutup yang kemudian diterjemahkan ke dalam bahasa statistika untuk kemudian diperoleh kesimpulan atas fenomena penelitian yang dilakukan. 


\section{HASIL PENELITIAN DAN PEMBAHASAN Hasil Pengujian Validitas}

Dalam pengujian validitas menggunakan SPSS 20, peneliti menguji keandalan setiap instrumen yang menjadi alat uji penelitian. Instrumen penelitian yang digunakan oleh peneliti adalah kuesioner dengan 33 pertanyaan yang berhubungan dengan kelima variabel yang diuji oleh peneliti. Pengujian validitas dilakukan dengan membandingkan $r_{\text {tabel }}$ dengan $r_{\text {hitung }}$, apabila nilai $r_{\text {hitung }}>$ nilai $r_{\text {tabel }}$, maka item tersebut adalah valid. Dari hasil pengujian, ternyata 33 item pertanyaan mempunyai nilai $r_{\text {hitung }}$ lebih besar daripada nilai $r_{\text {tabel }}$. Berdasarkan hal ini maka dapat disimpulkan bahwa 33 pertanyaan kuesioner penelitian merupakan pertanyaan yang valid

\section{Hasil Pengujian Reabilitas}

Pengujian reabilitas dilakukan untuk menguji apakah suatu instrumen dapat dipercaya dan diandalkan, sehingga ketika penelitian diulang, maka hasilnya tetap sama. Konsistensi suatu jawaban ditunjukkan dengan seberapa tingginya koefisien Gutman Split-Half. Berdasarkan hasil pengujian diperoleh besaran koefisien Gutman Split-Half sebesar 0,961. Hal ini berarti bahwa koefisien berada pada kategori yang sangat kuat, sehingga kita dapat menyatakan instrumen penelitian ini telah teruji reabilitasnya

\section{Analisis Regresi}

Analisis pengujian hipotesis penelitian ini menggunakan regresi berganda. Pengujian ini digunakan untuk menguji pengaruh SPI, kompensasi, kecerdasan emosi, dan pengamalan nilai-nilai spiritual terhadap kepatuhan aparatur negara dalam prosedur pengadaan barang dan jasa di Kabupaten Kediri.

\section{Tabel 1}

Hasil Pengujian Hipotesis

\begin{tabular}{|l|r|r|r|r|}
\hline Model & R & R Square & $\begin{array}{c}\text { Adjusted R } \\
\text { Square }\end{array}$ & $\begin{array}{c}\text { Std. Error of the } \\
\text { Estimate }\end{array}$ \\
\hline 1 & $0,902^{\mathrm{a}}$ & 0,814 & 0,807 & 0,54687 \\
\hline
\end{tabular}

a. Prediksi : (Constant), Pengamalan_Nilai_Spiritual, SPI, Kecerdasan_Emosi

b. Variabel Dependen : kepatuhan

Sumber : data diolah 
Berdasarkan hasil tabel 1 di atas, dapat diketahui bahwa besarnya nilai adjusted $R$ Square sebesar 0,814 yang berarti variabilitas variabel kepatuhan aparatur negara terhadap prosedur pengadaan barang dan jasa yang dapat dijelaskan oleh variabilitas SPI, kompensasi, kecerdasan emosi dan pengamalan nilai-nilai spiritual sebesar $81,4 \%$ sedangkan $18,6 \%$ dijelaskan oleh variabel lain yang tidak termasuk dalam penelitian ini.

Tabel 2

Hasil Uji Signifikasi Simultan

ANOVA $^{\mathrm{a}}$

\begin{tabular}{|rl|r|r|r|r|r|}
\hline Model & \multicolumn{1}{|c|}{$\begin{array}{c}\text { Sum of } \\
\text { Squares }\end{array}$} & Df & Mean Square & F & Sig. \\
\hline \multirow{3}{*}{1} & Regression & 145,211 & 4 & 36,303 & 121,387 &, $000^{\mathrm{b}}$ \\
& Residual & 33,196 & 111 &, 299 & & \\
& Total & 178,407 & 115 & & & \\
\hline
\end{tabular}

a. Variabel Dependen: Kepatuhan

b. Prediksi: (Constant), Pengamalan_Nilai_Spiritual, Kompensasi, SPI,

Kecerdasan_Emosi

Pengujian pengaruh simultan ( $F$ test) pada tabel 5.9, didapatkan $\mathrm{F}_{\text {hitung }}$ sebesar 121,387 dengan signifikansi pada 0,000 .Signifikasi $0,000<0,05$ yang berarti bahwa model regresi dapat digunakan untuk memprediksi kepatuhan aparatur negara terhadap prosedur pengadaan barang dan jasa, atau dapat dikatakan variabel SPI, kompensasi, kecerdasan emosi dan pengamalan nilai-nilai spiritual berpengaruh terhadap kepatuhan aparatur negara dalam prosedur pengadaan barang dan jasa.

Tabel 3

Hasil Uji Signifikasi Parsial Coefficients $^{\text {a }}$

\begin{tabular}{|ll|r|r|r|r|r|}
\hline Model & \multicolumn{2}{|c|}{$\begin{array}{c}\text { Unstandardized } \\
\text { Coefficients }\end{array}$} & $\begin{array}{c}\text { Standardized } \\
\text { Coefficients }\end{array}$ & \multirow{2}{*}{ Sig. } \\
\cline { 2 - 6 } & \multicolumn{2}{|c|}{ B } & Std. Error & \multicolumn{1}{|c|}{ Beta } & & \\
\hline \multirow{2}{*}{ (Constant) } &, 276 &, 189 & & 1,462 &, 147 \\
& SPI &, 812 &, 140 &, 798 & 5,778 &, 000 \\
& Kompensasi &,- 046 &, 039 &,- 050 & $-1,178$ &, 241 \\
& Kecerdasan_Emosi &, 355 &, 168 &, 302 & 2,112 &, 037 \\
& Pengamalan_Nilai_Spirit &,- 212 &, 162 &,- 188 & $-1,315$ &, 191 \\
\hline
\end{tabular}

a. Variabel Dependen: Kepatuhan 
Keempat variabel independen yang dimasukkan ke dalam model regresi hanya dua variabel saja yang mempunyai hasil signifikan. Hal ini dapat dilihat dari probabilitas signifikansi untuk variabel SPI sebesar 0,000 dan variabel kecerdasan emosi sebesar 0,037, dimana keduanya dibawah angka 0,05. Berdasarkan hal itulah dapat disimpulkan bahwa kedua variabel tersebut berpengaruh terhadap kepatuhan aparatur pemerintah dalam prosedur pengadaan barang dan jasa.

Sedangkan variabel kompensasi mempunyai probabilitas signifikasi sebesar 0,241 dan variabel pengamalan nilai-nilai spiritual sebesar 0,191, dimana keduanya mempunyai probabilitas signifikasi di atas angka 0,05. Berdasarkan hal itulah dapat disimpulkan bahwa kedua variabel tersebut tidak berpengaruh terhadap kepatuhan aparatur pemerintah dalam prosedur pengadaan barang dan jasa. Berdasarkan hasil analisis regresi diatas dapat dibuat persamaan sebagaimana berikut :

$\mathrm{Y}=0,276+0,812 \mathrm{X}_{1}+0,355 \mathrm{X}_{3}$

Dimana :

$\mathrm{Y}=$ Kepatuhan aparatur pemerintah terhadap prosedur pengadaan barang/jasa

$\mathrm{X}_{1}=$ Sistem Pengendalian Internal

$\mathrm{X}_{3}=$ Kecerdasan Emosi

\subsection{Pengujian Hipotesis}

Berdasarkan pada hasil uji signifikasi parsial pada tabel 3 di atas, dapat diuraikan hasil pengujian hipotesis sebagai berikut :

Tabel 4

Keputusan Hipotesis

\begin{tabular}{|l|l|c|c|l|}
\hline No & \multicolumn{1}{|c|}{ Variabel } & $\mathbf{t}_{\text {hitung }}$ & \multicolumn{1}{|c|}{\begin{tabular}{c}
\multicolumn{1}{|c|}{$\mathbf{t}_{\text {tabel }}$} \\
$\mathbf{d f}=\mathbf{1 1 4}$ (116-2)
\end{tabular}} & \multicolumn{1}{|c|}{$\begin{array}{c}\text { Keputusan } \\
\text { Hipotesis }\end{array}$} \\
\hline 1 & SPI & 5,778 & $>1,980$ & Diterima \\
\hline 2 & Kompensasi & $-1,178$ & $<1,980$ & Ditolak \\
\hline 3 & Kecerdasan Emosi & 2,112 & $>1,980$ & Diterima \\
\hline 4 & Pengamalan Nilai Spiritual & $-1,315$ & $<1,980$ & Ditolak \\
\hline 5 & $\begin{array}{l}\text { SPI, Kompensasi, Kecerdasan } \\
\text { Emosi, Pengamalan Nilai Spiritual } \\
\text { (Uji Simultan) }\end{array}$ & $\begin{array}{c}\text { Adjusted R Square }=0,807 \\
\text { (Berpengaruh) }\end{array}$ & Diterima \\
\hline
\end{tabular}




\section{Pembahasan Hasil Penelitian}

\section{Pengaruh SPI terhadap Kepatuhan Prosedur pengadaan barang/jasa}

Hasil uji hipotesis menunjukkan bahwa hipotesis 1 diterima, berarti data empiris mendukung hipotesis yang mengatakan SPI berpengaruh signifikan terhadap kepatuhan aparatur pemerintah dalam prosedur pengadaan barang dan jasa. Penelitian ini menggunakan teori keagenan eksekutif dan aparatur pemerintah untuk menjelaskan hubungan yang terjadi di lingkungan penelitian, dimaana kepala daerah sebagai prinsipal sedangkan seluruh pelaksana pengadaan barang/jasa pada setiap satuan kerja perangkat daerah sebagai agen. Hubungan kerja di antara kepala daerah dan pengelola tampak mulai bermasalah ketika kepentingan agen tidak lagi selaras dengan kepentingan pinsipal selaku pemilik organisasi. Prinsipal memiliki kepentingan untuk memaksimalkan keuntungan mereka sedangkan agen memiliki kepentingan untuk memaksimalkan pemenuhan kebutuhan ekonomi dan psikologisnya. Konflik akan terus meningkat karena prinsipal tidak dapat mengawasi aktivitas agen sehari-hari untuk memastikan bahwa agent telah bekerja sesuai dengan keinginan dari prinsipal. Menghadapi perkembangan tersebut dalam teori agensi dijelaskan bahwa prinsipal dapat mengeluarkan biaya tambahan untuk meningkatkan efektivitas pengawasan. Penelitian ini menemukan hubungan meningkatnya kepatuhan agen apabila terdapat SPI yang kuat. Agen akan merasa diawasi dalam melakukan pekerjaannya sehingga kesempatan agen untuk melakukan hal menyimpang semakin kecil dan kecenderungan agen untuk berbuat patuh melaksanakan prosedur pengadaan barang/jasa semakin besar. Di lain pihak, dengan SPI yang kuat akan mendorong prinsipal lebih mempercayai kinerja agen, karena prinsipal yakin agen telah melakukan berbagai prosedur yang telah ditentukan terkait pengadaan barang/jasa.

\section{Pengaruh Sistem Kompensasi terhadap Kepatuhan Prosedur pengadaan barang/jasa}

Hasil uji hipotesis menunjukkan bahwa hipotesis 2 ditolak, berarti data empiris tidak mendukung hipotesis yang mengatakan sistem kompensasi berpengaruh signifikan terhadap kepatuhan aparatur pemerintah dalam prosedur pengadaan barang/jasa. Temuan dalam penelitian ini konsisten dengan laporan yang diberikan Tang dan Chiu (2003), Wilopo (2006), Sartono (2006), Sulistyowati (2007) yang menyebutkan bahwa pendapatan yang diberikan dapat meningkatkan komitmen organisasi namun tidak menurukan perilaku ketidaktaatan terhadap peraturan organisasi. Penelitian ini menunjukkan bahwa yang berpengaruh terhadap semakin 
menurunnya perilaku tidak taat aturan bukan jumlah pendapatan yang diterimanya melainkan rasa menghargai dan syukur terhadap pendapatan tersebut.

\section{Pengaruh Kecerdasan Emosi terhadap Kepatuhan Prosedur pengadaan barang/jasa}

Hasil uji hipotesis menunjukkan bahwa hipotesis 3 diterima, berarti data empiris mendukung hipotesis yang mengatakan kecerdasan emosi berpengaruh signifikan terhadap kepatuhan aparatur pemerintah dalam prosedur pengadaan barang dan jasa. Respon responden terhadap variabel kecerdasan emosi memberikan gambaran bahwa sebagian besar responden menyatakan setuju dan sangat setuju terhadap kemanfaatan emosi yang ditata bagi tujuan hidupnya. Dengan demikian, responden menyetujui adanya kesadaran diri, pengaturan diri, empati, dan kemampuan sosial yang ditata sedemikian rupa sehingga bermanfaat bagi tujuan hidupnya. Hasil dalam penelitian ini konsisten dengan penelitian Svyantek dan Rahim (2002) dan Vakola, et al. (2004), yang membuktikan terdapat hubungan yang erat antara kecerdasan emosi seseorang dengan kepatuhan. Seseorang yang mempunyai kecerdasan emosi tinggi akan cenderung melakukan perilaku patuh terhadap peraturan yang berlaku di lingkungan dia berada.

\section{Pengaruh Pengamalan Nilai-nilai Spiritual terhadap Kepatuhan Prosedur pengadaan barang/jasa}

Hasil uji hipotesis menunjukkan bahwa hipotesis 4 ditolak, berarti data empiris tidak mendukung hipotesis yang mengatakan pengamalan nilai-nilai spiritual berpengaruh signifikan terhadap kepatuhan aparatur pemerintah dalam prosedur pengadaan barang/jasa. Penelitian ini konsisten dengan penelitian Thoyibatun (2009), yang menjelaskan bahwa seseorang bisa memliki spiritual sebagai sekedar pengetahuan atau kekayaan mind, atau di tingkatkan sebagai sikap, ataupun sebagai jiwa dari perilakunya. Ketika pemahaman nilai-nilai spiritual terhenti pada bidang pengetahuan saja, perilaku seseorang berkembang pada sisi terpisah dan menjadi bagian yang lain dari pengetahuannya tentang nilai-nilai spiritual. Jika keadaan demikian merupakan alternatif yang dipilih seseorang, wajarlah bagi seseorang tersebut untuk berperilaku apa saja tanpa memperdulikan pengetahuan nilai-nilai spiritual yang menjadi miliknya. Namun, hasil penelitian ini tidak mendukung penelitian Giacalone dan Jurkewicz (2003), Tikollah (2005) dan Weaver dan Agle (2002) yang menunjukkan bahwa derajat spiritual berpengaruh terhadap perasaan seseorang terhadap praktik bisnis apakah dipandang sebagai perbuatan yang baik atau buruk, dan apakah sesuai aturan atau menyimpang dari aturan. 


\section{Pengaruh Sistem Pengendalian Internal, Sistem Kompensasi, Kecerdasan Emosi dan Pengamalan Nilai-nilai Spiritual Pada Kepatuhan Aparatur Pemerintah Terhadap Prosedur Pengadaan Barang/Jasa dalam Uji Simultan}

Hipotesis 5 menyatakan bahwa terdapat pengaruh signifikan SPI, kompensasi, kecerdasan emosi dan pengamalan nilai-nilai spiritual terhadap kepatuhan aparatur pemerintah terhadap prosedur pengadaan barang/jasa. Berdasarkan data pada tabel 5.8 diketahui bahwa nilai adjusted $R$ square sebesar 0,807 yang berarti bahwa SPI, kompensasi, kecerdasan emosi dan pengamalan nilai-nilai spiritual berpengaruh sekitar $80,7 \%$ terhadap tindakan kepatuhan aparatur pemerintah pada prosedur pengadaan barang/jasa. Persentase $80,7 \%$ merupakan prosentase yang besar dan dan kuat. Berdasarkan persentase nilai adjusted $R$ square tersebut peneliti menyimpulkan hipotesis 5 diterima.

Hasil penelitian ini selaras dengan hasil penelitian yang dilakukan oleh Thoyibatun (2009). Walaupun dalam uji parsial menunjukkan hanya sistem pengendalian internal dan kecerdasan emosi yang mempunyai pengaruh signifikan terhadap kepatuhan, namun dalam uji simultan ternyata keempat faktor tersebut mempunyai peran yang signifikan terhadap kepatuhan jika keempat faktor tersebut dapat diaplikasikan secara bersama-sama. Penelitian ini membuktikan bahwa untuk menjadikan seorang manusia menjadi benar-benar patuh terhadap suatu peraturan maka diperlukan suatu ketundukan yang sukarela dibandingkan dengan ketundukan yang berasal dari paksaan. Oleh karena itu, pengembangan faktor dari luar (SPI dan kompensasi) maupun dari dalam diri manusia (kecerdasan emosi, pengamalan nilainilai spiritual) itu sendiri harus dipupuk untuk menjadikan kepatuhan itu bersifat sukarela dan bertahan lama dalam diri seseorang.

\section{KESIMPULAN}

\section{Kesimpulan Penelitian}

Hasil studi yang telah dilakukan menunjukkan bahwa faktor kompensasi dan pengamalan nilai-nilai spiritual secara parsial tidak berpengaruh terhadap kepatuhan aparatur pemerintah, sedangkan faktor sistem pengendalian internal dan kecerdasan emosi seseorang secara parsial berpengaruh positif terhadap kepatuhan aparatur pemerintah. Penelitian ini juga menemukan bukti bahwa keempat faktor yang diteliti, yaitu sistem pengendalian internal, kompensasi, kecerdasan emosi, pengamalan nilai-nilai spiritual secara simultan berpengaruh terhadap terjadinya kepatuhan aparatur pemerintah pada prosedur pengadaan barang/jasa. Temuan penelitian ini memberikan informasi kepada pihak-pihak berwenang bahwasanya dalam upaya peningkatan kepatuhan aparatur pemerintah terhadap prosedur pengadaan barang/jasa tidak selalu dengan memberikan kompensasi yang besar, jika pemberian kompensasi itu tidak diikuti dengan sistem pengendalian internal 
yang kuat. Sistem pengendalian internal yang kuat juga harus diimbangi dengan pembentukan kesadaran diri tiap-tiap individu untuk sadar menjadi seseorang yang patuh terhadap peraturan. Pembentukan kesadaran diri tersebut dalam hal ini dapat dibangun melalalui kecerdasan emosi seseorang dan pengamalan nilai-nilai spiritual.

\section{DAFTAR PUSTAKA}

Agustian, A.G. (2001). ESQ: Rahasia membangun kecerdasan emosi dan spiritual, berdasar 6 rukun iman dan 5 rukun islam. Arga, Jakarta.

Agustian, A.G. (2004). ESQ Power : Rahasia sukses membangkitkan sebuah inner journey melalui al-ihsan. Arga, Jakarta.

Arifiyani, H.A., \& Sukirno. (2012). Pengaruh Pengendalian Intern, Audit Kepatuhan dan Kompensasi Manajemen Terhadap Kepatuhan Karyawan (Studi Kasus pada Karyawan PT Adi Abadi Yogyakarta). Jurnal Nominal Volume I No. I. Fakultas Ekonomi. Universitas Negeri Yogyakarta.

Bachri, S. (2004). Perilaku Kerja Karyawan STMT Trisakti Jakarta. Disertasi tidak dipublikasikan. Program Pascasarjana Universitas Jakarta.

Baiman, S. (1990). Agency research in managerial accounting: a second look. Accounting, Organizations and Society, 15 (4), 341-371.

Bodnar, G.H., \& Hopwood, W.S. (2004). Accounting Information Systems, ninth edition. Pearson Education International.

COSO. (1998). Does your control system pass the COSO test?. Institute of Internal Auditors.

Dallas, L.L. (2002). A Preliminary inquiry into the responsibility of corporations and their directors and officers for corporate climate: the psycology of enron's demise. Diunduh 5 Desember 2013, dari www.ssrn.com

D' Aquila, J.M. (2001). Financial accountants's perception of management's ethical standards. Journal of Bussines Ethic.31(3):233-224.

D' Aquila, J.M. (1998). Is the control environment related to financial reporting decisions?. Managerial Auditing Journal, 13(8), 472-478. 
Giacalone, R.A. \& Jurkiewicz, C.L. (2003). Right from wrong: the influence of spirituality on perceptions of unethical business activities. Journal of Business Ethics, 46 (1), 85-95.

Goleman, D. (2003). Kecerdasan Emosional. Jakarta : PT Gramedia Pustaka Utama.

Goleman, D. (2005). Kecerdasan Emosi Untuk Mencapai Puncak Prestasi. Jakarta : PT Gramedia Pustaka Utama.

Gusnardi. (2008). Pengaruh peran komite audit, internal control dan internal audit dalam pelaksanaan good corporate governance dan pencegahan fraud (Studi pada BUMN terbuka di Indonesia). Disertasi tidak dipublikasikan. Program Pascasarjana Universitas Padjajaran, Bandung.

Hermiyetti. (2010). Pengaruh penerapan pengendalian internal terhadap pencegahan fraud pengadaan barang. Jurnal STEKPI Jakarta.

Ikatan Akuntan Indonesia. (2011). Standar Profesional Akuntan Publik : Standar Auditing Seksi 316, Pertimbangan Atas Kecurangan dalam Audit Laporan Keuangan.

Jensen, M.C., \& Meckling, W.H. (1976). Theory of the Firm: Mangerial Behavoir, Agency Cost, and Ownership Structure. University of Rochester. Rochester.

Jensen, M.C. (1986). Agency cost and free cash flow, corporate finance and takeover. American Economic Review, 76, 232-339.

Ludigdo, U. (2004). Pendidikan akuntansi berbasis IESQ untuk mengembangkan perilaku etis akuntan. TEMA, 5(2), 1-17.

Lui, F.T. (1985). An equilibrium queuing model of bribery. Journal of Political Economy, 93 (4), 760-781.

Ribstein, L.E. (2002). Market vs regulatory responses to corporate fraud: a critique of the sarbanes oxley act of 2002. Working Paper . Diunduh 28 Desember 2013, dari www.ssrn.com

Robbins, S.P. (2001). Organizational Behavior. 2001. Jakarta : PT. Indeks.

Romney, M.B., \& Steinbart, P.J. (2004). Accounting Information System, Ninth Edition. Jakarta : Salemba Empat. 
Sartono. (2006). Analisis faktor-faktor yang mempengaruhi penyimpangan pada pengadaan barang/jasa di lingkungan instansi pemerintah. Tesis tidak dipublikasikan. Universitas Indonesia, Jakarta.

Sulistiyowati, T. (2007). Pengaruh Kepuasan Gaji dan Kultur Organisasi Terhadap Persepsi Aparatur Pemerintah Daerah Tentang Tindak Korupsi. JAAI, 11, $47-66$.

Svyantek, D.J., \& Rahim, M.A. (2002). Links between emotional intellegence \& behavior in organization : finding empirical studies. The International Journal of Organizational Analysis, 10 (4), 299-301.

Tikollah, M.R. (2005). Pengaruh kecerdasan intelektual, kecerdasan emosional, dan kecerdasan spiritual terhadap sikap etis mahasiswa akuntansi. Tesis tidak dipublikasikan. Universitas Brawijaya, Malang.

Triyuwono, I. \& Roekhuddin. (2000). Konsistensi praktik sistem pengendalian intern dan akuntanbilitas pada lazis jakarta. Jurnal ilmu-ilmu Sosial.

Triyuwono, I. (2002). Kearifan lokal: internalisasi "sang lain" dalam dekonstruksi pengukuran kinerja manajemen. Seminar Regional Sehari. FE Universitas Brawijaya, Malang.

Tuanakotta, T.M. (2009). Menghitung Kerugian Keuangan Negara Dalam Tindak Pidana Korupsi. Jakarta : Salemba Empat.

Vakola, M., Tsausis, I., \& Nikolau, I. (2004). The role of emotional intelligence \& personality variables on attitude toward organizational change. Journal of Managerial Psychology, 19 (1/2), 88-103.

Watt, R.L, \& Zimmerman, J.L. (1986). Positive accounting theory. New Jersey : Prentice Hill.

Weaver, G.R., \& Agle, B.R. (2002). Religiosity and ethical behavior in organization : a symbolic interactionist perspective. Academy of Management Review, 22 (1), 77-97.

Wilopo. (2006). Analisis faktor-faktor yang berpengaruh terhadap kecenderungan kecurangan akuntansi : studi pada perusahaan publik dan badan usaha milik negara di indonesia. Makalah Simposium Nasional Akuntansi 